\title{
Proteostasis Dysregulation in Pancreatic Cancer
}

\section{Arpalahti, Leena}

Springer

2020

Arpalahti , L , Haglund , C \& Holmberg , C I 2020 , Proteostasis Dysregulation in Pancreatic Cancer . in R Barrio , J D Sutherland \& M S Rodriguez (eds), PROTEOSTASIS AND DISEASE: FROM BASIC MECHANISMS TO CLINICS : From basic Mechanisms to Clinics . Advances in Experimental Medicine and Biology, vol. 1233, Springer, Cham , pp. 101-115 . https://doi.org/10.1007/978-3-030-38266-7_4

http://hdl.handle.net/10138/328900

https://doi.org/10.1007/978-3-030-38266-7_4

unspecified

acceptedVersion

Downloaded from Helda, University of Helsinki institutional repository.

This is an electronic reprint of the original article.

This reprint may differ from the original in pagination and typographic detail.

Please cite the original version. 
Huomasimme vasta, että tulokset ovat analysoitu käyttäen joko OS tai DFS:ää; aiemmin olemme kuitenkin käyttäneet (kaikki kolme artikkelia) disease specific/cancer specificsurvivalia (DSS/CSS), joka poikkeaa näistä kahdesta. Esim. DFS ja DSS erona on potilaan poistuminen analyysistä kun potilas sairastuu uudelleen vs. kuolee tautiin

Mitä mieltä olette, olisi varmaan tämän huomioiden hyvä analysoida tulokset DSS:ää käyttäen?

Jos katsotaan tämän hetkisiä tuloksia, sekä OS:n että DFS:n mukaan suolessa ryhmäjako näyttää mielestämme järkevimmin osuvan 0-2 vs 3? (kuten Reetta oli aiemmin tehnyt)

Maksan kohdalla taas on vaikeampi sanoa OS:n tai DFS:n mukaan mikä oli järkevin ryhmäjako, ja tästä kannattaisi varmaan keskustella yhdessä?

Tammikuun tulosten sivun 10 perusteella (crostabb elossa/kuollut) vaikuttaisi kuitenkin, että korkea UCHL5 sekä suolessa ja maksassa on potilaan kannalta parempi. Mahdollisesti myös jos maksan UCHI5-taso on suolta alhaisempi, tästä seuraa huonompi ennuste.

Marraskuun alaryhmä-analyyseistä maksa/primaarituumorilokaatio (sivut 7) ja ikä (s. 9 ja 10) kannattaa varmaan tehdä uudestaan, kunhan saamme päätettyä lopullisen ryhmäjaon.

Ohessa vielä edustusmikroskooppikuvat suolesta ja maksasta sekä muutama kuva samasta potilaasta molemmista kudoksista ja distribuutioyritelmä.

Sopisiko teille uusi lyhyt palaveri esim. hiihtoloman jälkeisellä esim. ke 26.2. koko päivän tai 25.2. ti aamupäivällä? 